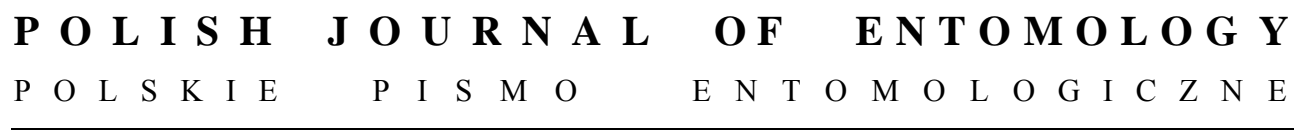

VOL. 81: 195-206

Gdańsk

30 September 2012

DOI: $10.2478 / \mathrm{v} 10200-012-0007-\mathrm{x}$

\title{
Systematics and faunistics of Grapholitini, 2: Ethelgoda HEINRICH, Ofatulena HeINRICH, Cyanocydia gen. n., and Metacydia gen. n.
}

\author{
JÓZEF RAZOWSKI ${ }^{1}$, VITOR O. BECKER ${ }^{2}$ \\ ${ }^{1}$ Institute of Systematics and Evolution of Animals, Polish Academy of Sciences, \\ Sławkowska 17, 31-016 Kraków, Poland, e-mail: Razowski@isez.pan.krakow.pl; \\ ${ }^{2}$ Reserve Serra Bonita, PO Box 01, 45880-970 Camacan, BA, Brazil, \\ e-mail: Becker.vitor@gmail.com
}

\begin{abstract}
Neotropical members of four genera of Grapholitini are treated: Ethelgoda HeINRICH, Ofatulena HeINRICH, Cyanocydia gen. n., and Metacydia gen. n. Five species are described as new: Ethelgoda escarcegae sp. n., E. anfracta sp. n., E. stynophra sp. n., Ofatulena lathetica sp. n., and Metacydia polyseta sp. n.
\end{abstract}

KEY WORDS: Tortricidae, Grapholitini, Neotropic, new taxa.

\section{INTRODUCTION}

The systematics and distribution of Neotropical Grapholitini are poorly known. This paper is one of a series of papers dealing with material from Central and South America. The faunistic data are based on collections primarily from Costa Rica, Brazil and Ecuador. In the course of the studies that comprise this series of papers, new species have been found in almost all known genera, but a few new genera are necessary as well (further papers are in preparation).

All the specimens were collected by the junior author; the types of the newly described species are deposited in the Becker Collection, Camacan, and will eventually be deposited in one of the Brazilian Museums. Some material has been kindly donated to the Institute of Systematics and Evolution of Animals, PAS, Kraków.

The numbers cited from the labels of the type material refer to the numbers in Becker's register book. Abbreviation: GS - genitalia slide. 


\section{Acknowledgements}

The authors thank Mr Witold Zajda, Kraków, for taking the photographs and arranging the plates.

\section{RESULTS}

\section{Ethelgoda HEINRICH, 1926}

Ethelgoda was described for the single Nearctic species E. texanana WALSINGHAM. According to the original description "the genus has hardly a single character to define it, yet on the sum of its characters it fits in none of the other genera." Externally, HEINRICH compared it with Talponia and stated that "on the male genitalia and abdominal characters it could go in Grapholitha". Its female genitalia, "except for the two signa, are those of Dichrorampha and its hind wing venation is that of Ricula".

\section{Description}

Based on the present material we provide the following summary of the genital characters of the genus.

Male genitalia. Socii plate-shaped, coalesced basally, hairless; sacculus angulate, rounded; ventral incision of valva large with straight or slightly convex median part of proximal edge; cucullus rather small with ventral lobe larger than dorsal lobe and caudal edge somewhat convex; aedeagus simple.

Female genitalia. Posterior part of sterigma weakly convex, lateral parts extending, connected with posterior, shallow pocket-like parts of the subgenital sterite; sclerite of antrum, median and proximal parts of ductus bursae developed; signa pair.

\section{Comments}

At present the genus includes seven species (four described by RAZOWSKI (2011) distributed from Texas to the Federal District in Brazil). It is close to Sereda HeINRICH, 1926 showing some similarities in the shape of the valva. On the other hand, it is related to Ofatulena HEINRICH, 1926, which has a similar sterigma-complex and only one signum (see the comments on Ofatulena).

\section{Ethelgoda texanana (WALSINGHAM, 1879)}

\section{Material examined}

Four males and one female from Chiapas, Mexico (Villa las Rosas, 1300 m, 27. VI. 1981 [43483]); British Virgin Island (Guana, X. 1989) and Cuba (Santiago: Siboney, 23. VI. 1990).

\section{Comments}

This species has been described from Texas, U.S.A. It is known from Florida, U.S.A., Cuba and Jamaica. 


\section{Ethelgoda escarcegae sp. $\mathbf{n}$.}

(Figs 1, 10)

\section{Diagnosis}

In facies, E. escarcegae is similar to E. texanana, but E. escarcegae can be distinguished by its male genitalia, in particular the large aedeagus and elongate ventral lobe of the cucullus, which is similar to that of E. anfracta. The latter species is characterized by the presence of a large lobe on the proximal edge of the ventral incision of the valva.

\section{Description}

Wing span $14 \mathrm{~mm}$. Head and thorax greyish. Forewing as in texanana, brownish, darker basally and submedially, creamer at end of median cell where there are a few brownish longitudinal lines; costal strigulae small, whitish; divisions brownish; several fine brown dots along dorsum. Markings reduced to indistinct edge of median fascia. Cilia brownish. Hindwing brown; cilia whitish.

Male genitalia (Fig. 1). Valva broad to middle; neck broad, bent; ventral incision deep; sacculus convexly rounded caudally; dorsal lobe of cucullus small, rounded; ventral lobe large, elongate, with ventro-caudal tip; aedeagus large, narrowing postmedially; cornuti with numerous spines.

Female not known.

\section{Material examined}

Holotype male: "Mexico: Campeche, Escarcega, 85 m, 12-17.VI.1981, V.O. Becker Col; Col. Becker 42962"; GS 468. Paratypes: Two identically labelled males.

\section{Etymology}

The specific name refers to the type locality.

\section{Comments}

One female from the same locality and same collecting number (GS 469) is externally similar to some specimens of texanana but shows slight differences in the genitalia.

\section{Ethelgoda anfracta sp. $\mathbf{n}$.}

(Figs 2, 7, 11)

\section{Diagnosis}

This species is distinguished by its pale colouration (brownish-white dorsal patch of forewing, brownish grey markings) and small size. The male genitalia are similar to those of E. escarcegae but are easily distinguished by the presence of a large lobe on the anterior edge of the ventral incision of the valva and a short aedeagus.

\section{Description}

Wing span $10 \mathrm{~mm}$. Head brownish-white, proximal part of thorax slightly darker. Forewing expanding terminad; costa slightly bent; termen concave below apex. Ground colour brownish white; suffusions and strigulation pale brownish olive; dorsal patch with 
three weak dividing lines; costal strigulae fine, white; divisions brownish; ocellar area indistinct; termen with a series of black dots. Markings slightly darker than strigulation consisting of dorsal part of postbasal fascia, costal portion of median fascia and subtornal marking. Cilia concolorous with ground colour, brownish posteriorly. Hindwing pale brownish grey; cilia whiter.

Variation. One paratype paler than described above, female paratype with more brown, distinct suffusions and markings.

Male genitalia (Fig. 2). Basal third of valva broad; ventral incision deep with large, rounded lobe on proximal edge; neck fairly broad; sacculus short, angulate; ventral lobe of cucullus large, extending ventro-caudally; aedeagus longer than sacculus, tapering terminad from beyond $1 / 3$.

Female genitalia (Fig. 7). Postostial part of sterigma large, extending latero-proximally; lateral lobes of subgenital sternite small; sclerite of antrum shorter than cingulum; proximal sclerite of corpus bursae large; signa small.

\section{Material examined}

Holotype male: Brasil: D[istrito]F[ederal], Planaltina 15.35'S 47.42'W, Brasil, $1000 \mathrm{~m}$, V.O. Becker Col; Col. Becker 56628"; GS 879. Paratypes: one female, same label data as holotype and two females, same label data, except 26.VIII.1986 and 3.IX.1984; GS 879.

Etymology

The specific epithet refers to shape of the valva; Latin: anfracta - broken down.

\section{Comments}

One male with a somewhat different shape and lobe on the anterior edge of the ventral incision of the valva.

\section{Ethelgoda stynophra sp. n.}

(Figs 3, 12)

\section{Diagnosis}

This species is closely related to E. okrodon RAZOWSKI, 2011 from Dominica, but stynophra has a longer neck of the valva, a broader ventral incision, a smaller dorsal lobe of the cucullus, and a reduced convexity of the proximal edge of the ventral lobe.

\section{Description}

Wing span $18 \mathrm{~mm}$. Head and thorax greyish, labial palpus cream. Forewing indistinctly expanding posteriorly; costa gradually convex; termen not oblique, weakly concave beneath apex. Wing brownish in dorsal part diffusely spotted whitish, costal area greyish; costal strigulae yellowish cream, two posterior ones large, white; divisions brownish; a few blackish brown vertical dashes on pale orange yellow patch at end of median cell; a similar suffusion at termen with three black dots and a subterminal suffusion. Markings reduced to indistinct brownish blotch before mid-termen. Cilia concolorous with dorsal part of wing. Hindwing brown paler basally, cilia creamer. 
Variation. One paratype, browner than holotype.

Male genitalia (Fig. 3). Basal part of valva broad with sacculus angulate, shorter than neck of valva; cucullus large with small dorsal lobe and large, ventrally-pointed ventral lobe; aedeagus short.

Female not known.

\section{Material examined}

Holotype male: "Costa Rica: Turrialba 600 m, IV. 1973, V.O. Becker Col; Col. Becker 37682"; GS 486. Paratypes: two males, same label data, except VII. 1981 and IX. 1972.

Etymology

The name refers to the dark colouration of the moth; Greek: stynophrys - gloomy.

\section{Ofatulena HEINRICH, 1926}

Originally, this genus was "affiliated with Laspeyresia (= Cydia HüBNER, [1825]) restricted to North America." According to BROWN (2005), three species were known. RAZOWSKI (2011) added four new species (from Costa Rica to Brazil), and one new species is described here.

According to the original description, the genus is distinct by having large spines along the ventral edge of the valva, the sacculus and neck [of valva] reduced, the uncus absent, "and the socii represented as wavy hair tufts at extremity of tegumen, and in the female genitalia there are two signa, ductus bursae unchitinized and the genital plate absent".

\section{Description}

The following data are based on the examined material.

Male genitalia. Uncus-like projection at top of tegumen (in type species densely hairy); socius a shallow concavity filled with setae; valva broad, usually with indistinct neck; sacculus simple, occasionally angulate; large ventral lobe of valva ventrally armed with strong spines, usually with an additional terminal lobe with one or two spines, rarely the lobe strongly reduced.

Female genitalia. Sterigma similar to that of Ethelgoda with more or less distinct anteostial part and weak lateral lobes similarly connected with posterior edge of the subgenital plate, which is weakly expressed; pocket-like structures of the latter weak; sclerites of ductus bursa are present (the antrum sclerite and cingulum); signum one.

\section{Ofatulena lathetica sp. n.}

(Figs 4, 8, 13)

\section{Diagnosis}

This species has a separate position within the genus despite the similar structure of the cucullus, which resembles that of $O$. duodecemstriata (WALSINGHAM, 1881) from Arizona, U.S.A. This species differs from the latter by the complete reduction of socii and the short 
spiny lobe of the valva armed with only five large spines; the shape of the sacculus is similar to some undescribed representatives of the genus. The female has the sterigma better developed than in other species of Ofatulena, and the shape of forewing is quite distinct.

\section{Description}

Wing span $9.5 \mathrm{~mm}$. Head and thorax grey, labial palpus whiter with brown-grey mark. Forewing not expanding posteriorly; costa straight to beyond $2 / 3$ where distinctly bent; apex very short; termen not oblique, straight to tornal part. Ground colour brownish grey with indistinct olive hue and some browner dots and strigulae, diffusely spotted blackish in posterior third. Markings indistinct, base of wing darker than adjacent part of ground colour; trace of postbasal fascia at indistinct dorsal patch, remnants of costal suffusion of median fascia. Cilia similar to ground colour. Hindwing brown; cilia white with some brown scales chiefly anally.

Variation. Female forewing paler, greyer than male, with more distinct markings; hindwing paler basally.

Male genitalia (Fig. 4). Uncus well developed, uniformly broad throughout; socius absent; valva rather slender with short neck and small ventral incision; sacculus with terminal prominence; cucullus curved upwards with subventral lobe armed with five large spines; aedeagus short, broad.

Female genitalia (Fig. 8). Sterigma small with well sclerotized lateral parts and slender proximal and distal edges limiting large ostium area; sclerite of antrum weak; signum rather small.

\section{Material examined}

Holotype male: "Brasil: D[istrito]F[ederal] Planaltina $1000 \mathrm{~m}, 15.35^{\prime} \mathrm{S} 47.42^{\prime} \mathrm{W}$, Brasil, 1000 m, V.O. Becker Col; Col. Becker 41054" GS 522. Paratypes: one male and one female, same label data, GS 521.

\section{Etymology}

The name refers to the shape of the forewing, which conceals the generic position of the species; Greek: latheticos - easily concealed.

\section{Metacydia gen. n.}

Type species: Metacydia polyseta sp. n.

\section{Diagnosis}

The single described species of this genus is externally similar to Ethelgoda, Ofatulena, and some Cydia HÜBNER, 1825, but it can be distinguished by the shape and vestiture of the valva. The numerous spiniform scales on the vinculum represent a male scent organ. 

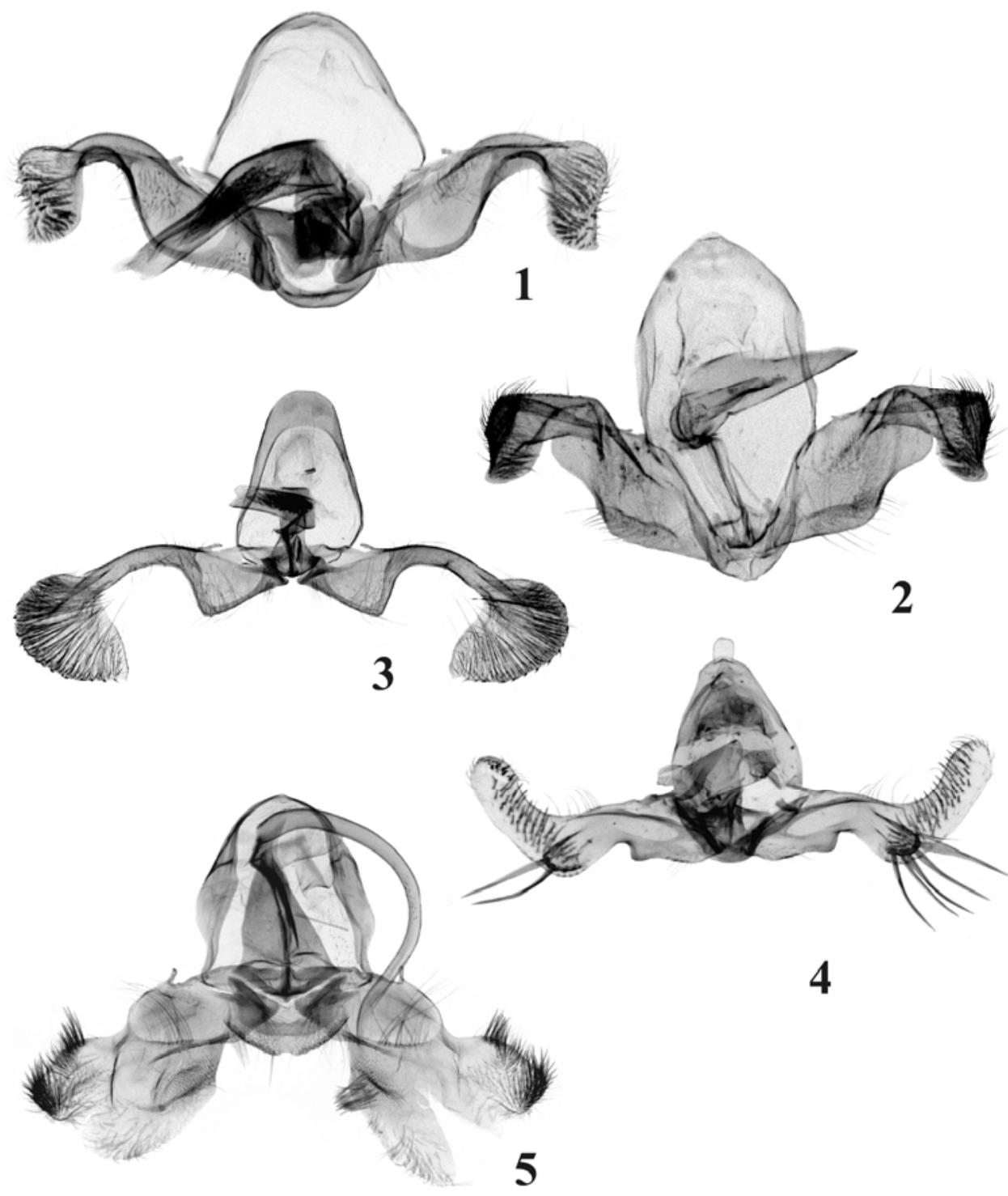

Figs 1-5. Male genitalia: 1 - Ethelgoda escarcegae sp. n., holotype, 2 - Ethelgoda anfracta sp. n., holotype, 3 - Ethelgoda stynophra sp. n., holotype, 4 - Ofatulena lathetica sp. n., holotype, 5 - Metacydia polyseta sp. n., holotype. 

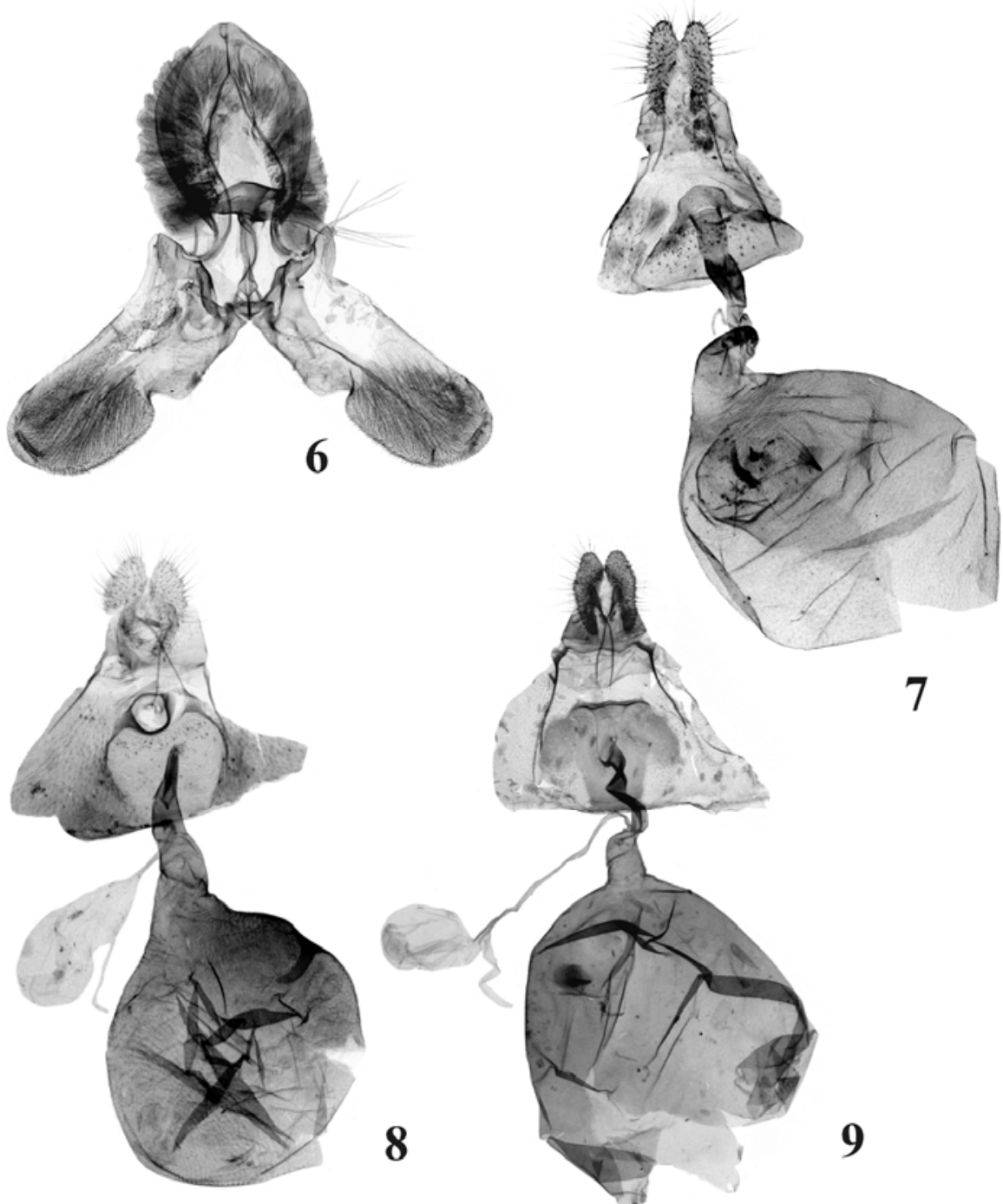

Figs 6-9. Female genitalia: 6 - Cyanocydia eucyanea Walsingham, Tamaulipas, Mexico, 7 - Ethelgoda escarcegae sp. n., paratype, 8 - Ofatulena lathetica sp. n., paratype, 9 - Cyanocydia eucyanea Walsingham, Tamaulipas, Mexico. 


\section{Description}

The facies of Metacydia are nearly identical to those described for Ethelgoda HEINRICH, 1926: labial palpus smooth, upcurved; forewing with all veins separate, R5 to termen, $\mathrm{CuA} 2$ beyond base of R1 oppositely (not clear what "oppositely" refers to); chorda and median stem present; hindwing with all veins separate except for M3-CuA1 which are connate.

Male genitalia. Tegumen with minute apical projection and slender pedunculi; subscaphium typical of the tribe; vinculum band-shaped; valva large with broad basal cavity marked by long hairs extending from middle of posterior edge; neck of valva short, broad; ventral incision subtriangular; groups of subventral short spines beyond neck and on costa beyond dorsal concavity; cucullus undifferentiated with similar dorso-caudal spines; olethreutoid (???) large; aedeagus very long, curved; cornuti not found.

Female not known.

\section{Etymology}

The generic name refers to the name of the genus Dichrorampha Guenée (not Cydia??) and the Greek: meta - different, behind.

\section{Metacydia polyseta sp. $\mathbf{n}$.}

(Figs 5, 14)

\section{Diagnosis}

The only species of the genus, $M$. polyseta is similar externally to Ethelgoda texanana (WALSINGHAM, 1879) and E. escarcegae sp. n. It can be distinguished by the shape and vestiture of the valve in the male genitalia.

\section{Description}

Wing span $15 \mathrm{~mm}$. Head and thorax brownish grey with olive hue; labial palpus brownish cream. Forewing broad, expanding somewhat terminally; costa slightly convex; termen weakly oblique, weakly sinuate beneath apex. Ground colour white-brown represented by transverse parallel lines extending from dorsum separated by brownish lines; costal strigulae concolorous, small; divisions brown; a few vertical dashes in median cell postbasally; termen suffused ferruginous; ocellar area brownish white with several black inner spots and traces of posterior refractive line. Markings indistinct, in form of brown postbasal and submedian lines extending posteriorly in median part of wing. Cilia brownish. Hindwing brown, glossy; cilia similar.

Male genitalia (Fig. 5) as described for the genus.

Female not known.

\section{Material examined}

Holotype male: "Brasil: RO[ndonia], Cacaulandia 200 m, 15-20.IV.1996, V.O. Becker Col; Col. Becker 107872"; GS 531. 


\section{Etymology}

The name refers to quantity of setae on the valva in the male genitalia; Greek: poly numerous.

\section{Cyanocydia gen. $\mathbf{n}$.}

(Figs 6, 9)

Type-species: Cydia eucyanea WALSINGHAM, 1914

\section{Diagnosis}

This genus shows some characters of Cydia HüBNER, [1825], e.g. the wing venation, shape of the wings, absence of the terminal row of dots of the forewing, and colouration. The male genitalia are distinguished by the very large, densely scaled socii (an autapomorphic character); the female genitalia are somewhat similar to those of the Dichrorampha-group of genera, having the sterigma included in the subgenital sterite. The posterior edge of the sterigma forms a well sclerotized rod fused with the posterior edge of the sternite; this character and the very long postostial sterigma may represent autapomorphies for the genus.

\section{Description}

Large species with broad forewing, blackish ground colour with several bluish refractive lines, lacking costal fold.

Male genitalia (Fig. 6). Tegumen fairly long with uncus-like prominence at the top; pedunculus slender proximally; socius very large, densely scaled; scales of socii broad, rather short; vinculum small; valva rather uniformly broad with distinct, sclerotized lobe at base of costa; sacculus simple, angulate; ventral incision of valva short; cucullus without lobes, minutely spined marginally and double row of thicker spines; aedeagus small, simple; cornuti not found (numerous sockets present); olethreutoid long. Group of long, filiform scent scales at base of pedunculus.

Female genitalia (Fig. 9). Ovipositor short; apophyses very slender; sterigma elongate, fused with subgenital sternite laterally, with small, slender anteostial part and rod-like posterior edge of postostial part; sclerite of antrum fused with postmedian sclerite of ductus bursae; one signum present. Proximal part of subgenital sternite slender.

Biology and distribution

Mexico (Veracruz, Tamaulipas) and Costa Rica. Moth collected in July at an altitude of $1000 \mathrm{~m}$.

\section{Etymology}

The name is a combination of the generic name Cydia and name of the type-species (cyan[o] - derived from eucyanea). 


\section{Cyanocydia eucyanea WALSINGHAM, 1914}

\section{Material examined}

Two specimens from Tamaulipas, Mexico (Gomes Farias, 1000 m, 29-31.VII.1988, V.O. Becker \& M.A. Solis).

\section{Comments}

This species was described from Veracruz, Mexico.

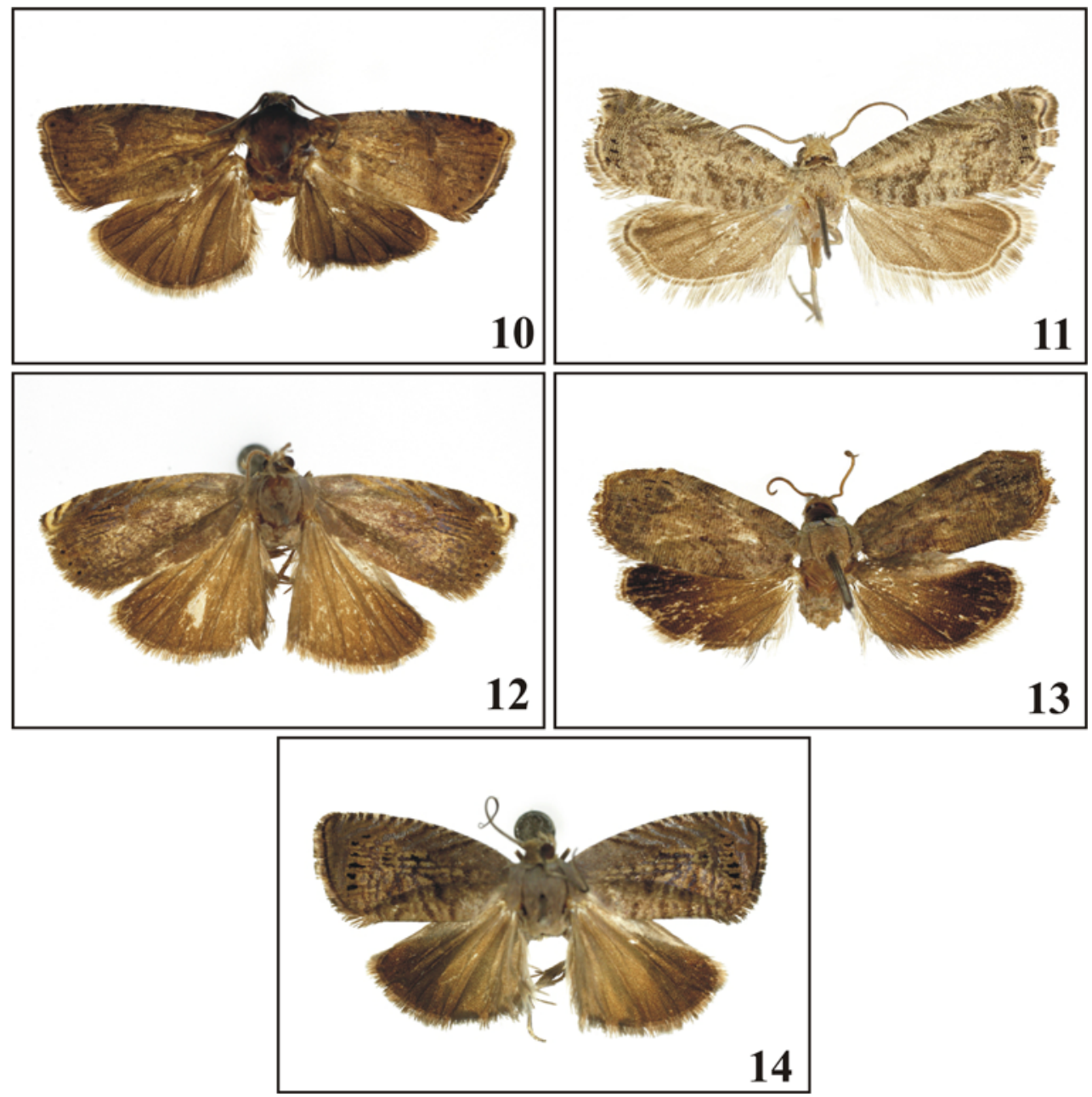

Figs 10-14. Adults: 10 - Ethelgoda escarcegae sp. n., holotype, 11 - Ethelgoda anfracta sp. n., holotype, 12 - Ethelgoda stynophra sp. n., paratype, 13 - Ofatulena lathetica sp. n., holotype, 14 - Metacydia polyseta sp. n., holotype. 


\section{REFERENCES}

BROWN J.W. 2005. Tortricidae (Lepidoptera). [In:] B. LANDRY. World Catalogue of Insects, vol. 5, $741 \mathrm{pp}$.

RAZOWSKI J. 2011. New species, new genera, and new combinations of Grapholotinia (Lepidoptera: Tortricidae) from the Neotropical Region. Acta Zoologica cracoviensia 53A(1-2): 37-101.

Received: April 12, 2012

Accepted: July 6, 2012 